\title{
Oxidative Stress Has a Negative Effect on the Development and Progression of Bladder Cancer
}

\author{
(D) Murat DEMiR, ${ }^{1}$ (i) Canan DEMiR ${ }^{2}$ \\ 'Department of Urology, Van Yuzuncu Yil University, Van-Turkey \\ ${ }^{2}$ Department of Medical Documentation and Secretarial Program, Van Yuzuncu Yil University, Vocational School of High of Health \\ Services, Van-Turkey
}

\begin{abstract}
OBJECTIVE
In this study, we aimed to investigate the oxidant-antioxidant capacity in bladder cancer according to invasion and degree.

\section{METHODS}

Forty-six patients with bladder cancer and 50 healthy volunteers were included in the study. After $12 \mathrm{~h}$ of fasting, $4 \mathrm{cc}$ of blood venous blood was taken from these patients. Then, after centrifugation at 5000 rpms for $10 \mathrm{~min}$, the serum portion of the study was completed. The activities of arylesterase (ARE), paraoxanase-1 (PON-1), glutathione reductase (GR), glutathione-S transferase, and protein carbonyl $(\mathrm{PC})$ in serum were measured spectrophotometrically.

\section{RESULTS}

Antioxidant parameters in the serum of patients with bladder tumors were found lower than control group ( $\mathrm{p}=0.001$ ). In addition, $\mathrm{PC}$ was found to be higher in the bladder cancer group than in the control group ( $\mathrm{p}=0.001$ ); on the other hand, ARE, PON-1, and GR levels were found to be lower in both highgrade tumors and invasive tumors $(\mathrm{p} \leq 0.05)$.
\end{abstract}

\section{CONCLUSION}

Oxidative stress is effective in the development and progression of bladder tumors.

Keywords: Bladder cancer; oxidants-antioxidants; oxidative stress.

Copyright $\odot$ 2022, Turkish Society for Radiation Oncology

\section{Introduction}

Bladder cancer, which is the third malignancy of the urinary system of frequency, is responsible for approximately $5 \%$ of cancer-related deaths.[1] Factors such as smoking, chemicals, urinary system infection, bladder stones, radiation exposure, and western style diet are blamed in the etiology.[2]

Etiological factors such as smoking and chemical agents are known to cause cancer by causing an increase in reactive oxygen radicals. Free oxygen rad- icals cause deterioration of many cell components, especially protein, lipid, and nucleic acid. Increased free oxygen radicals are associated with cancer risk through lipid peroxidation and protein oxidation. In addition, free oxygen radicals and oxidative stress affect nucleic acids and cause oncogenic mutations and tumoral growth. $[3,4]$ However, there is a balance between oxidant and antioxidant structures. Disruption of this balance in favor of oxidant contributes to tumor development. Antioxidants have an anti-tumoral effect because they prevent oxidation. Along with 
many minerals and vitamins in the body, many enzymes have antioxidant properties.[4]

There are endogenous oxidant and antioxidant structures in the human body. Protein carbonyl (PC), an oxidant, is the end product of protein oxidation. It has been shown that this structure is increased in colon and breast cancer.[5] Paraoxanase-1 (PON-1) and arylesterase (ARE) are endogenous antioxidant enzymes. These usually act together and act by binding to the lipoprotein. The levels of these two enzymes have been shown to decrease in colon cancer.[6] Glutathione reductase (GR) and glutathione $S$ transferase (GST) are the most well-known antioxidants. These act on glutathione and inactivate oxidant structures. It has been shown that the decrease in the levels of these two enzymes is effective in the development of colorectal cancer.[7]

In this study, we aimed to measure PON-1, ARE, GST, GR enzyme activities, and PC, which is a protein oxidation product, which plays a role in antioxidant mechanisms in the body and in bladder cancer.

\section{Materials and Methods}

This prospective study was performed between April 2021 and October 2021, after receiving governmental ethics commission approval (Ethics Number: 31.03.2021-22). Transurethral resection tumor (TUR-T) was performed in 63 patients with suspected bladder tumors and not taking any active treatment. Thirteen patients were excluded from this study because their pathology results were benign or because of a pathology other than urothelial carcinoma, and 4 patients were excluded because of additional systemic diseases. Forty-six patients whose histopathological results were defined as transitional cell carcinoma after TUR-T and hospital staff, 50 healthy patients were included in the study. The control group was formed by matching the study group with the patients in terms of gender and age. Among the patients in both groups, those with active infection, additional systemic disease (diabetes mellitus, vasculitis, chronic kidney, liver disease, etc.), chronic alcohol and drug use were excluded from the study. In addition, patients with additional cancer in the study group and any cancer in the control group were excluded from the study.

\section{Blood Collection}

All patients in the control and study groups stopped all food and drink intake at $9 \mathrm{pm}$. At $9 \mathrm{am}$, after they had been fasting for $12 \mathrm{~h}$, intravenous blood was drawn from all patients before the operation. The drawn blood was kept at $+4^{\circ} \mathrm{C}$ with the help of ice cubes. Then, after centrifugation at $5000 \mathrm{rpms}$ for 10 min, the serum portion of the study was completed. The obtained serum samples were kept at $-80^{\circ} \mathrm{C}$ to await for biochemical analysis.

\section{PC}

The Reznick and Packer method (1994) was used to determine the plasma PC level. This method is based on the spectrophotometric measurement (Shimadzu UV1601 Japan) of the color formed by the proteins in the plasma with 2.4-dinitrophenylhydrazine.[8]

\section{$\mathrm{ARE}$ and PON-1}

PON-1 activity of 4-nitrophenol, which is formed as a result of enzymatic hydrolysis when paraoxon $(\mathrm{O}, \mathrm{O}-$ diethyl-O-p-nitrophenyl phosphate; Sigma Co, London, UK.), is used as a substrate. ARE activity, on the other hand, was determined by measuring the colored product given by phenol, which is formed as a result of enzymatic hydrolysis of Phenyl Acetate (Sigma Co, UK), which is then used as a substrate in Techcomp 8500 II UV/VIS spectrophotometer (Techcomp Ltd., China).[9]

- UNIT=1nmol 4-nitrophenol/L serum/min for PON-1 activity

- UNIT=1 micromol $\mathrm{phenol} / \mathrm{ml}$ serum $/ \mathrm{min}$ for ARE activity.

\section{GST and GR}

The GST activity was determined using the Habig et al.[10] method. The GR level was measured as described by Beutler.[11]

\section{Statistical Analysis}

Descriptive statistics for continuous variables; the mean was expressed as Standard Deviation, while Categorical Variables were expressed as numbers and percentages. In comparisons that were made in terms of continuous variables, Student t-test was used for those with normal distribution and Mann-Whitney U-test for those without normal distribution. Pearson correlation coefficients were calculated separately for the groups in order to determine the relationship between continuous variables. The statistical significance level was taken as $5 \%$ in the calculations and the SPSS (Version:21, IBM Corporation, Armonk, NY) statistical package program was used for the calculations. 


\section{Results}

For this study, there were 46 bladder cancer patients included in the study group, and 50 healthy individuals in the control group. While the mean age of the patients in the study group was $62.80 \pm 10.74$, it was $62.42 \pm 10.55$ in the control group $(\mathrm{p}=0.86)$. The study group had $8(17.3 \%)$ female patients and $38(82.6 \%)$ male patients, and the control group had 9 (17.4\%) females and $41(82.6 \%)$ males. While the body mass index of the patients in the study group was $28.5 \pm 3.46$, it was $28.96 \pm 3.64$ in the control group $(\mathrm{p}=0.52)$. The tumor grade of 30 patients $(65.2 \%)$ was identified as low grade, while $16(34.7 \%)$ patients' tumors were identified as high grade. The tumor invasion rate of $35(76 \%)$ patients was T0, while 11 (23.9\%) patients had a tumor invasion rate of $\mathrm{T} 1$. While all biochemical parameters were significantly different in the patient group compared to the healthy control group, when we evaluate the study group within itself, there were significant differences in tumor grades and invasion rates in all parameters except GST and PC enzymes (Tables 1-3).

\section{Discussion}

In this study, it was shown that PC, which is one of the protein oxidation products, was significantly higher and antioxidant enzymes ARE, PON-1, GR, and GST were found to be low in patients with bladder cancer. In addition, this data show the importance of oxidative stress factors in bladder cancer patients.

Free oxygen radicals that are formed as a result of oxidative stress cause the deterioration in lipid, protein, nucleic acids and carbohydrate structures in cells. In addition, reactive oxygen species first cause the peroxidation of unsaturated fatty acids found in the cell membrane structure. As a result of peroxidation in the cell membrane structure, deterioration in the structure and functions of the cell begins to occur.[12] Malondialdehyde (MDA), which is released as a result of lipid peroxidation, is used as a marker of oxidative stress.[13] However, apart from fatty acids, proteins are also affected by free oxygen radicals. As a result of the effect of free radicals, separation in the peptide structures and deterioration in the structure of the protein occur.[14] Compared with MDA, PC, which is a protein oxidation product, has the advantage that it is released earlier and that the PC level will remain stable for a long time, while lipid peroxidation products disappear within minutes.[15] In addition, PC can be stored for 3 months for analysis if kept at

\begin{tabular}{lccc} 
Table 1 & \multicolumn{3}{c}{$\begin{array}{c}\text { Comparison of biochemical parameters be- } \\
\text { tween bladder cancer and control groups }\end{array}$} \\
$\begin{array}{l}\text { Oxidant and } \\
\text { antioxidants }\end{array}$ & $\begin{array}{c}\text { Patients } \\
(\mathbf{n = 4 6 )}\end{array}$ & $\begin{array}{c}\text { Control group } \\
(\mathbf{n = 5 0 )}\end{array}$ & $\mathbf{p}$ \\
\hline ARE & $3.2 \pm 0.05$ & $7.03 \pm 0.07$ & $0.001^{*}$ \\
PON-I & $1.06 \pm 0.03$ & $2.28 \pm 0.03$ & $0.001^{*}$ \\
GR & $0.23 \pm 0.02$ & $0.50 \pm 0.03$ & $0.001^{*}$ \\
GST & $2.05 \pm 0.02$ & $4.14 \pm 0.02$ & $0.001^{*}$ \\
PC & $5.04 \pm 0.02$ & $2.25 \pm 0.05$ & $0.001^{*}$ \\
\hline
\end{tabular}

*Significant difference was found between the patients and healthy groups in ARE, PON-1, GR, GST, and PC levels. (Student t-test). ARE: Arylesterase; PON-1: Paraoxanase-1; GR: Glutathione reductase; GST: Glutathione-S transferase; PC: Protein carbonyl

Table 2 Comparison of biochemical parameters among patients with bladder tumors according to tumor grades

\begin{tabular}{lccc}
$\begin{array}{l}\text { Oxidant and } \\
\text { antioxidants }\end{array}$ & \multicolumn{2}{c}{ Tumor grades } & p \\
\cline { 2 - 3 } & $\begin{array}{c}\text { Low grade } \\
(\mathbf{n = 3 0 )}\end{array}$ & $\begin{array}{c}\text { High grade } \\
(\mathbf{n = 1 6 )}\end{array}$ \\
\hline ARE & $3.21 \pm 0.04$ & $3.18 \pm 0.04$ & $0.03^{*}$ \\
PON-1 & $1.07 \pm 0.03$ & $1.04 \pm 0.02$ & $0.01^{*}$ \\
GR & $0.23 \pm 0.01$ & $0.22 \pm 0.01$ & $0.04^{*}$ \\
GST & $2.05 \pm 0.02$ & $2.05 \pm 0.01$ & 0.95 \\
PC & $5.04 \pm 0.02$ & $5.04 \pm 0.02$ & 0.68 \\
\hline
\end{tabular}

*A significant difference was observed between low grade and high grade groups in terms of ARE, PON-1, and GR values (Mann-Whitney $U$ test). ARE: Arylesterase; PON-1: Paraoxanase-1; GR: Glutathione reductase; GST: Glutathione-S transferase; PC: Protein carbonyl

Table 3 Comparison of biochemical parameters among patients with bladder tumors according to tumor invasion level

\begin{tabular}{llcc} 
Oxidant and & \multicolumn{2}{c}{ Invasion levels } & p \\
antioxidants & T0 (n=35) & T1 (n=11) & \\
\cline { 2 - 3 } & $3.21 \pm 0.04$ & $3.17 \pm 0.04$ & 0.006 \\
\hline ARE & $1.06 \pm 0.03$ & $1.04 \pm 0.02$ & 0.02 \\
PON-1 & $0.23 \pm 0.01$ & $0.22 \pm 0.01$ & 0.03 \\
GR & $2.05 \pm 0.02$ & $2.05 \pm 0.01$ & 0.78 \\
GST & $5.04 \pm 0.02$ & $5.04 \pm 0.02$ & 0.70 \\
PC &
\end{tabular}

${ }^{*} \mathrm{~A}$ significant difference was observed between T0 and T1 groups in terms of ARE, PON-1, and GR values (Mann-Whitney U test). ARE: Arylesterase; PON-1: Paraoxanase-1; GR: Glutathione reductase; GST: Glutathione-S transferase; PC: Protein carbonyl

$-80^{\circ} \mathrm{C}$ and is relatively easier to detect when compared to MDA.[15,16] Over the past decade, many studies have been published reporting increased PC levels in various diseases, and it has been shown to have a good 
correlation with the severity of these diseases. [17-19] In our study, the presence of PC has also shown its association with bladder cancer.

Oxidative stress, which is effective in cancer development, occurs as a result of imbalances between oxidant and antioxidant mechanisms. Whongsiri, Patcharawalai et al.[20] stated that oxidative stress can trigger urothelial carcinomas and antioxidants can be used in defense. Wieczorek et al.[21] reported that antioxidant deficiency (catalase, superoxide dismutase, and glutathione peroxidase) is effective in the development of bladder tumors and low antioxidant levels in cases that relapse after TUR-T. Among the other antioxidant enzymes, we used in our study, both PON-1 and ARE enzymes are in esterase structures. PON-1 enzymes that are circulating with high-density lipoprotein in the circulation protects low-density lipoproteins against oxidation, as PON-1 interacts with ARE enzymes in this function. It has also been observed that decreases in PON-1 and ARE activities are associated with many diseases, including cancer. [22-25] In the study conducted by Michalak et al.,[26] no correlation was found between the presence and severity of ovarian cancer and the activities of these enzymes. However, in our study, a decrease in the activity of these enzymes was detected with both the presence of bladder cancer and the increase in the degree and invasion of the disease. Although there was a difference in enzyme activities between the groups in the study of Michalak et al., it was thought that there was no statistically significant difference due to the small number of patients.

Glutathione is an important point in the oxidative mechanism. It provides inactivation of intracellular xenobiotics and increases cell resistance against free oxygen radicals.[4,27] In case of intracellular deficiency, fatty acids and free fatty acids in the cell membrane are easily oxidized by free oxygen radicals. Two of the most important enzymes in the glutathione mechanism are the GR and GST enzymes, as these enzymes play an important role in cell defense.[2831] In the study of Gecit et al.,[32] GST enzyme levels were found to be low in bladder tissues, but the relationship of these parameters with regards to tumor grade and invasion rate was not investigated.In our study, the GR and GST enzyme levels of patients were significantly lower than those of the control group.

In our study, it was observed that oxidant and antioxidant levels are important in terms of tumor progression and aggressiveness, as well as their effect on the development of bladder tumors. In addition, oxidative stress parameters may be prognostic factors for bladder cancer and may also contribute to its diagnosis, and may also lead to the development of therapies in cancer treatment. Therefore, we think that this study makes important contributions to the literature. The limiting factor of our study is that oxidant and antioxidant structures were not measured in patient urine and tissue samples.

\section{Conclusion}

We think that oxidative stress is effective in the development as well as in the exacerbation of its degree and invasion, but that antioxidant mechanisms are protective. For this reason, we believe that antioxidants can be used in future treatment modalities. However, this study should be supported by additional, more voluminous studies.

Acknowledgment: The authors thank Halit Demir for the biochemical analysis of the blood.

Peer-review: Externally peer-reviewed.

Conflict of Interest: All authors declared no conflict of interest.

Ethics Committee Approval: The study was approved by The Van Yüzüncü Yıl University Interventional Clinical Research Ethics Committee (No: 22, Date: 31/03/2021).

Financial Support: This study has received no financial support.

Authorship contributions: Concept - M.D.; Design M.D., C.D.; Supervision - M.D., C.D.; Funding - M.D., C.D.; Materials - M.D., C.D.; Data collection and/or processing M.D., C.D.; Data analysis and/or interpretation - M.D., C.D.; Literature search - M.D., C.D.; Writing - M.D., C.D.; Critical review - M.D., C.D.

\section{References}

1. Bray F, Ferlay J, Soerjomataram I, Siegel R, Torre LA, Jemal A. Global cancer statistics 2018: GLOBOCAN estimates of incidence and mortality worldwide for 36 cancers in 185 countries. CA Cancer J Clin 2018;68(6):394-424.

2. Jahrreiss V, Pradere B, Laukhtina E, Mori K, Shariat SF. Catalog of exogenous risk factors for bladder carcinogenesis. Curr Opin Urol 2020;30(3):449-56.

3. Sharma C, Yang W, Steen H, Freeman MR, Hemler ME. Antioxidant functions of DHHC3 suppress anti-cancer drug activities. Cell Mol Life Sci 2021;78(5):2341-53.

4. Gunes M, Eryilmaz R, Aslan R, Taken K, Demir H, 
Demir C. Oxidant-antioxidant levels in patients with bladder tumours. Aging Male 2020;23(5):1176-81.

5. Kundaktepe BP, Sozer V, Durmus S, Kocael PC, Kundaktepe FO, Papila C, et al. The evaluation of oxidative stress parameters in breast and colon cancer. Medicine (Baltimore) 2021;100(11):e25104.

6. Afsar CU, Gunaldı M, Okuturlar Y, Gedikbası A, Tiken EE, Kahraman S, et al. Paraoxonase-1 and arylesterase activities in patients with colorectal cancer. Int J Clin Exp 2015;8(11):777-80.

7. Lorestani S, Hashemy SI, Mojarad M, Keyvanloo SM, Bahari A, Asadi, M, et al. Increased glutathione reductase expression and activity in colorectal cancer tissue samples: An investigational study in Mashhad, Iran. Middle East J Cancer 2018;9(2):99-104.

8. Reznick AZ, Packer L. Oxidative damage to proteins: spectrophotometric method for carbonyl assay. Methods Enzymol 1994;233:357-63.

9. Juretic D, Tadijanovic M, Rekic B, Simoen RV, Reiner E, Baricic M. Serum paraoxonase activities in hemodialyzed uremic patients: cohort study. Croat Med J 2001;42(2):146-50

10. Habig WH, Pabst MJ, Jakoby WB. Glutathione Stransferases. The first enzymatic step in mercapturic acid formation. J Biol Chem 1974;249(22):7130-9.

11. Beutler E. Red cell metabolism. A manual of biochemical methods. Orlando, FL: Gune and Stratton; 1984.

12. Jakubczyk K, Dec K, Kaldunska J, Kawczuga D, Kochman J, Janda K. Reactive oxygen species - sources, functions, oxidative damage. Pol Merkur Lekarski 2020;48(284):124-7.

13. Lepara Z, Lepara O, Fajkić A, Rebic D, Alic J, Spahovic $\mathrm{H}$. Serum malondialdehyde (MDA) level as a potential biomarker of cancer progression for patients with bladder cancer. Rom J Intern Med 2020;58(3):146-2.

14. Wang Z, Li S, Cao Y, Tian X, Zeng R, Liao DF, et al. Oxidative stress and carbonyl lesions in ulcerative colitis and associated colorectal cancer. Oxid Med Cell Longev 2016;2016:9875298.

15. Costa NA, Gut AL, Azevedo PS, Fernandes AAH, Polegato BF, Cunha NB, et al. Protein carbonyl, but not malondialdehyde, is associated with ICU mortality in patients with septic shock. J Intensive Care Med 2019;34(8):669-73.

16. DalleDonne I, Milzani A, Colombo R. H2O2-treated actin: assembly and polymer interactions with crosslinking proteins. Biophys J 1995;69(6):2710-9.

17. Musolino C, Alonci A, Allegra A, Saija A, Penna G, Cannavo $\mathrm{A}$, et al. Increase in serum protein carbonyl groups is associated with more advanced stage of disease in multiple myeloma patients. Biomarkers 2011;16(8):718-9.

18. Panis C, Victorino VJ, Herrera, Freitas LF, De Rossi T, Campos Fc, et al. Differential oxidative status and immune characterization of the early and advanced stages of human breast cancer. Breast Cancer Res Treat 2012;133(3):881-8.

19. Avezov K, Reznick, AZ, Aizenbud D. Time and dose effects of cigarette smoke and acrolein on protein carbonyl formation in HaCaT keratinocytes. Adv Exp Med Biol 2015;849:57-64.

20. Whongsiri P, Phoyen S, Boonla C. Oxidative stress in urothelial carcinogenesis: measurements of protein carbonylation and intracellular production of reactive oxygen species. Methods Mol Biol 2018;1655:109-17.

21. Wieczorek E, Jablonowski Z, Tomasik B, Gromadzinska J, Jablonska E, Konecki T, et al. Different gene expression and activity pattern of antioxidant enzymes in bladder cancer. Anticancer Res 2017;37(2):841-8.

22. Cervellati C, Bonaccorsi G, Trentini A, Valachi G, Sanz J, Squerzanti M, et al. Paraoxonase, arylesterase and lactonase activities of paraoxonase-1 (PON1) in obese and severely obese women. Scand J Clin Lab Invest 2018;78(1-2):18-24.

23. Romani A, Trentini A, Flier W, Bellini T, Zuliani G, Cervelatti C, et al. Arylesterase activity of paraoxonase-1 in serum and cerebrospinal fluid of patients with Alzheimer's disease and vascular dementia. Antioxidants 2020;9(5):456.

24. Khodayar MJ, Seghatoleslami M, Salehcheh M. Paraoxonase and arylesterase activities in patients with cancer. Iran J Blo and Cancer 2017;9(1):5-11.

25. Arenas M, Rodríguez E, Sahebkar A. Paraoxonase-1 activity in patients with cancer: A systematic review and meta-analysis. Crit Rev Oncol Hematol 2018; 127:6-14.

26. Michalak S, Szubert S, Moszynski R, Sajdak S, Szpurek D. Serum arylesterase and paraoxonase activities in patients with ovarian tumors. Taiwan J Obstet Gynecol 2014;53(4):490-3

27. Kennedy L, Sandhu JK, Harper ME, Cuperlovic M. Role of glutathione in cancer: from mechanisms to therapies. Biomolecules 2020;10(10):1429.

28. Bansal A, Simon MC. Glutathione metabolism in cancer progression and treatment resistance. J Cell Biol 2018;217(7):2291-8.

29. Kalinina EV, Gavriliuk LA. Glutathione synthesis in cancer cells. Biochemistry 2020;85(8):895-7.

30. Nunes SC, Serpa J. Glutathione in ovarian cancer: a double-edged sword. Int J Mol Sci 2018;19(7):1882.

31. Desideri E, Ciccarone F, Ciriolo MR. Targeting glutathione metabolism: partner in crime in anticancer therapy. Nutrients 2019;11(8):1926.

32. Gecit I, Eryılmaz R, Kavak S, Gecit I, Meral I, Demir $\mathrm{H}$, et al. The prolidase activity, oxidative stress, and nitric oxide levels of bladder tissues with or without tumor in patients with bladder cancer. J Membrane Biol 2017;250(5):455-9. 